\title{
Prevalence of Malaria and Some Opportunistic Infections in Human Immunodeficiency Virus/Acquired Immune Deficiency Syndrome (HIV/AIDS) Patients with CD4 Below 200 in Faith Alive Hospital, Jos, Plateau State, Nigeria
}

\author{
Dawet $A^{*}$ and Onaiyekan $O E$ \\ Department of Zoology, University of Jos, Nigeria
}

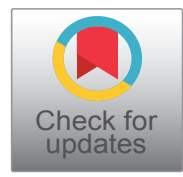

*Corresponding author: Anthony Dawet, Department of Zoology, University of Jos, Nigeria

\begin{abstract}
The human immunodeficiency virus (HIV) infection leads to Acquired Immunodeficiency Syndrome (AIDS) resulting to a progressive decline in the immune system of people living with HIVIAIDS (PLWHA) making them susceptible to a variety of opportunistic infections which eventually leads to death. This study aimed at determining the prevalence malaria and some opportunistic infections in HIVIAIDS patients with CD4 count below 200 attending Faith Alive Hospital, Jos, Plateau State. The testing for opportunistic infections was done using thick and thin blood films for haemoparasites, formal ether concentration technique for stool, sedimentation technique for urine for intestinal parasites and modified Ziehl-Neelsen's technique to examine the sputum for bacteria and other parasites. Higher infection of 96 (96\%) out of the 100 patients examined was recorded. Of this, malaria was the most common infection with $86(86.0 \%)(\mathrm{P}<$ $0.05) .6(6.0 \%)$ were tested positive for tuberculosis and 4 $(4.0 \%)$ had cryptosporidiosis while $4(4.0 \%)$ had no infection. The study reveals that most HIVIAIDS patients with CD4 below 200 were infected and there is need for regular checkup and prophylaxis to reduce the prevalence of these infections.
\end{abstract}

\section{Keywords}

Malaria, Opportunistic infections, CD4 count, HIVIAIDS

\section{Introduction}

Opportunistic infections (OIs) are infections that occur more frequently and are more severe in individuals with weakened immune systems, including people with HIV. Ols are less common now than they were in the early days of HIV and AIDS because better treatments reduce the amount of HIV in a person's body and keep a person's immune system stronger. However, many people with HIV still develop Ols because they may not know of their HIV infection, they may not be on treatment, or their treatment may not be keeping their HIV levels low enough for their immune system to fight off infections (https://www.cdc.gov/hiv/basics/livingwithhiv/opportunis ticinfections. htm/ 02/01/2018. $9.08 \mathrm{am}$ ).

Since the start of the epidemic, issues related to Human Immunodeficiency Virus/Acquired Immune Deficiency Syndrome (HIV/AIDS) has had a high profile in developed countries. However, the burden of disease continues to fall most heavily, and often less visibly, in developing countries, particularly Africa [1]. HIV can eventually cause AIDS by attacking a type of white blood cell called CD4 cells. These are the same cells in the immune system that are supposed to protect the body from disease. The US Centers for Disease Control and Prevention $(C D C)$ define a person living with HIV (HIV+) and with a CD4 cell count of 200 or less as having AIDS. People are also diagnosed with AIDS if they have or have had one of the AIDS-defining conditions (http:// www.thewellproject.org/hiv-information/what-are-opportunistic-infections 02/01/2018 $9.21 \mathrm{am}$ ).

Human Immunodeficiency Virus (HIV)/Acquired Immunodeficiency Syndrome (AIDS) have already infected more than forty million people worldwide

Citation: Dawet A, Onaiyekan OE (2020) Prevalence of Malaria and Some Opportunistic Infections in Human Immunodeficiency Virus/Acquired Immune Deficiency Syndrome (HIV/AIDS) Patients with CD4 Below 200 in Faith Alive Hospital, Jos, Plateau State, Nigeria. Int J Virol AIDS 7:058. doi. org/10.23937/2469-567X/1510058

Accepted: January 25, 2020: Published: January 27, 2020

Copyright: (C) 2020 Dawet A, et al. This is an open-access article distributed under the terms of the Creative Commons Attribution License, which permits unrestricted use, distribution, and reproduction in any medium, provided the original author and source are credited. 
and are continuing to spread at an alarming rate. All efforts are being made to fight HIV/AIDS. Currently no HIV/AIDS vaccines are approved for use, though many are in clinical trial studies. Neither has the spread of HIV stopped nor is the management of HIV cases satisfactory. The progress and outcome of HIV/ AIDS is influenced by factors such as baseline health, nutritional status, environment, endemic diseases and access to therapy [2]. HIV causes progressive depletion of the CD4 T cells, resulting in conditions known as opportunistic infections. More than $90 \%$ of these are responsible for AIDS morbidities and mortalities. Once CD4T cell count falls below 200 cells/ $\mu$ l, risk of Ols increases dramatically and the patient is said to have progressed to AIDS and patients generally succumbs to death [3]. Increased incidence of Ols was seen in individuals with low CD4 counts. Ols rate was very high (58\%) when the CD4 counts were $<200$ cells/ $\mu \mathrm{l}$. As the CD4 count increases the incidence of Ols is decreased. The rate of Ols were $41 \%$ when CD4 counts were $200-500$ cells/ $\mu$ land it was just $1 \%$ when the CD4 counts were $>500$ cells/ $\mu$ l [4].

People with advanced HIV are vulnerable to infections called 'opportunistic infections' (Ols) because they take advantage of the opportunity offered by a weakened immune system. Before the widespread of potent combination antiretroviral therapy (ART), opportunistic infections (OIs), were more severe because of immunosuppression in HIV-infected persons [3]. Malwal, et al. [5] reported that the prevalence of opportunistic infections in HIV infected patients at Kyenyata National Hospital was $14.1 \%(95 \% \mathrm{Cl}$ : 10.7-18.5). Overall, the most commonly reported bacterial infection was pneumonia (6.4\%) whereas pulmonary tuberculosis was reported in $3.6 \%$ of patients. Although the presence of ART drugs has not completely removed opportunistic infections. The relative frequencies of specific opportunistic diseases may vary in different countries and even in different areas within the same country. Prospective and retrospective studies identified 200 CD4 cells per cubic millimeter to be the most susceptible group to opportunistic infections [6].

\section{Materials and methods}

\section{Study area}

The research was carried out at Faith Alive Foundation, Jos, Plateau State, from December 2016-March 2017. Jos is located in the middle belt of Nigeria. Faith Alive Hospital is a centre where most HIV/AIDS patients within and outside the state attend their medical checkups.

\section{Ethical approval}

Ethical clearance was sought and obtained from the Medical Director of the hospital. The study was conducted in accordance with the guidelines by the National Centre for Health Research Ethics. Study population.

A total of 100 adult HIV patients from 18 years above who had CD4T cells below 200 and were visiting the hospital for their antiretroviral drugs whose consent was sought and agreed to enter the investigation were enrolled for the study.

\section{Collection of samples}

This was carried out as described by [7]. Blood samples were collected in Ethylene Diethyl (EDTA) bottles, while urine, stool and sputum samples were collected in sterile universal bottles and a sterile swab stick was used for the collection of high virginal swab, endocervical swab and wound swab. All the samples (blood, urine, stool and sputum) were collected from each patient.

\section{Determination of HIV and CD4T cells}

HIV was determined following the method of [8]. The presence of HIV-1 antibodies in the serum was determined using rapid HIV-1 diagnostic test kits following the manufacturers' instructions. The sera were first tested with Determine HIV-1/2. Negative results were further tested with Capillus HIV-1/2. If the result of Capillus was found negative, then the serum was considered as negative for HIV antibodies. HIV positive cases showed two red lines/band and HIV negative cases showed one red band. FACS count microbead-based system is a microbead-based single-platform instrument that was used to count CD4T cells and other helper cells in the whole blood. The blood sample was put in a twin-tube reagent tubes, fluorochrome-labeled antibodies in the reagents binded specifically to lymphocyte surface antigens. A fixation solution was added, the sample was run on the instrument. The calculation of absolute CD3, CD4 and CD8 T-cells was determined automatically by using built-in Attractors software programme.

\section{Determination of infections}

These were determined using the methods of [9]. Thick and thin blood smears were tested for malaria parasite using Giemsa staining techniques, direct wet mount, sedimentation and concentration methods were used for the stool and urine samples for helminthes eggs and adults and Ziehl-Neelsen's method (Acid Fast Bacilli) was used to examine bacteria on sputum samples.

\section{Statistical analysis}

Data collected were calculated using percentage and analyzed using Chi square method. $\mathrm{P}<0.05$ were considered significant.

\section{Results}


The present study showed that out of 100 HIV patients examined, $96(96.0 \%)$ were infected while four [4] did not have any infection (Table 1). Among those infected, Malaria had the highest infection 86 (86.0\%), followed by tuberculosis which recorded $6(6.0 \%)$ infection while cryptosporidiosis had the least infection 4 (4.0\%).

The infection according to age showed that malaria was highest amongst ages 15-35 years with a prevalence of 34 (94.44\%), followed by age group $36-55$ years with 45 (83.33\%), age group $56-75$ years with a $6(75.0 \%)$ while age group $76-95$ years had the least infection of 1 (50.0\%) (Table 2). The age group with the highest tuberculosis infection was ages 5675 with $12.5 \%$, followed by age group 36-55 with $7.41 \%$, age group $15-35$ with $2.78 \%$ while there was no tuberculosis infection amongst those from ages 76

Table 1: Prevalence of Infections among HIVIAIDS Patients $(n=100)$.

\begin{tabular}{|l|l|}
\hline Opportunistic infections & Number infected (\%) \\
\hline Malaria & $86(86.0 \%)$ \\
\hline Tuberculosis & $6(6.0 \%)$ \\
\hline Cryptosporidiosis & $4(4.0 \%)$ \\
\hline Total & $96(96.0 \%)$ \\
\hline
\end{tabular}

and above. The study recorded that cryptosporidiosis had significantly $(P<0.05)$ higher infection $(50.0 \%)$ amongst those from ages 76 and above accompanied by those within age $56-75$ with $12.5 \%$ infection, age group $36-55$ with $3.70 \%$ while no cryptosporidiosis was recorded amongst those within age group 15-35. The infection was significantly difference $(P<0.05)$ amongst the different age groups.

Out of the 100 HIV/AIDS patients examined, 60 were females while 40 were males. Table 3 shows that female patients had higher malaria prevalence 55 (91.67\%) than their male counterpart 31 (77.50\%). On the contrary, the male recorded higher $(7.50 \%$ each) infection in tuberculosis and cryptosporidiosis than the females which had the prevalence of $5.0 \%$ and $1.67 \%$ respectively. The differences in the sex had no significant $(P>0.05)$ effect in the prevalence of infection among the HIV patients.

Infection according to CD4 count showed that patients with CD4 150 and below recorded highest (100\%) infection compared with $91.30 \%$ encountered in those with CD4 between $151=200$ (Table 4). There was no significant $(p>0.05)$ difference in infection between the different $C D 4$ groups.

\section{Discussion}

Table 2: Prevalence of Infections among HIVIAIDS Patients in Relation to Age Group.

\section{Number (\%) with opportunistic infections}

\begin{tabular}{|l|l|l|l|l|}
\hline Age group & Number examined & Malaria & Tuberculosis & Cryptosporidiosis \\
\hline $15-35$ & 36 & $34(94.44) \mathrm{a}^{*}$ & $1(2.78)$ & $0(00)$ \\
\hline $36-55$ & 54 & $45(83.33) \mathrm{a}^{*}$ & $4(7.41)$ & $2(3.70)$ \\
\hline $56-75$ & 8 & $6(75.0) \mathrm{a}^{*}$ & $1(12.5)$ & $1(12.5)$ \\
\hline 76 and above & 2 & $1(50.0) \mathrm{a}^{*}$ & $0(00)$ & $1(50.0)^{*}$ \\
\hline Total & 100 & $86(86.0) \mathrm{a}^{*}$ & $6(6.0)$ & $4(4.0)$ \\
\hline
\end{tabular}

Values are significant at $\mathrm{P}<0.05$, while column with common letter superscript has no significant difference $\mathrm{P}>0.05$.

Table 3: Prevalence of Infections among HIVIAIDS Patients According to Sex Group.

\section{Number (\%) with opportunistic infections}

\begin{tabular}{|l|l|l|l|l|}
\hline Sex & Number examined & Malaria & Tuberculosis & Cryptosporidiosis \\
\hline Male & 40 & $31(77.5) \mathrm{a}^{*}$ & $3(7.50)$ & $3(3.50)$ \\
\hline Female & 60 & $55(91.67) \mathrm{a}^{*}$ & $3(5.0)$ & $1(1.67)$ \\
\hline Total & 100 & $86(86.0)^{*}$ & $6(6.0)$ & $4(4.0)$ \\
\hline
\end{tabular}

Values are significant at $P<0.05$, while column with common letter superscript has no significant difference $P>0.05$.

Table 4: Prevalence of Infections among HIVIAIDS Patients in Based on CD4 count.

CD 4 count

\begin{tabular}{|l|l|l|l|l|}
\hline Opportunistic infection & $\mathbf{0 - 5 0}(\mathbf{n = 1 9})$ & $\mathbf{5 1 - 1 0 0}(\mathbf{n}=\mathbf{1 6})$ & $\mathbf{1 0 1 - 1 5 0}(\mathbf{n}=\mathbf{1 9})$ & $\mathbf{1 5 1 - 2 0 0}(\mathbf{n}=\mathbf{4 6})$ \\
\hline Malaria & $17(89.47) \mathrm{a}^{*}$ & $16(100) \mathrm{a}^{*}$ & $16(84.21) \mathrm{a}^{*}$ & $37(80.43) \mathrm{a}^{*}$ \\
\hline Tuberculosis & $1(5.26)$ & $0(00)$ & $3(15.79)$ & $2(4.35)$ \\
\hline Cryptosporidiosis & $1(5.26)$ & $0(00)$ & $0(00)$ & $3(6.52)$ \\
\hline Total & $19(100) \mathrm{a}^{*}$ & $16(100) \mathrm{a}^{*}$ & $19(100) \mathrm{a}^{*}$ & $42(91.30) \mathrm{a}^{*}$ \\
\hline
\end{tabular}

"Values are significant at $P<0.05$, while row with common letter superscript has no significant difference at $P>0.05$. 
The high prevalence of opportunistic infections in HIV/AIDS patients reported in this area is higher than the $28.0 \%$ infection reported in Aurangabad, India [10]. The prevalence of tuberculosis and cryptosporidiosis in this study were lower than the 51\% and $24 \%$ infection respectively in East Godavari district, Andhra Pradesh [4]. Malaria being the most prevalent infection in HIV/AIDS patients in this report is not consistence with [4] who reported that tuberculosis (51\%) was the common Ol followed by candidiasis (39\%), Cryptosporidium diarrhea (24\%). Contrary to this, Cryptosporidium spp. (20.8\%) was found to be the most common parasite among intestinal pathogens among HIV patients in Aurangabad, India [10]. It also varies with [11] who reported that Cryptosporidium was the most common parasite isolated $15.87 \%$, followed by Isospora $10.02 \%$ and Cyclospora $5.84 \%$ in HIV-positive patients with diarrhea respectively [12]. Reported that tuberculosis was the second most frequent opportunistic disease $(n=120,11.0 \%)$ after candidiasis (16.2\%) in HIV infected patients in Korea.

The higher prevalence of tuberculosis and cryptosporidiosis in patient greater than 30 years and malaria in younger patients in the current study is in agreement with [13] who reported consistently higher prevalence of opportunistic infection in older age groups ( $>30$ years) before and after HAART for oral candida and tuberculosis and higher in young age groups (<30 years) for malaria and genital ulcers. According to [8] the majority of individuals infected with opportunistic diseases were found in the age group 25-34 years of HIV/AIDS (34.6\%) \& HIV positive healthy carriers (28.1\%) but 15 24 of HIV negative individuals (31.4\%) [14]. Reported highest prevalence of cryptosporidiosis (33.33\%) and isosporiasis $(30.5 \%)$ among patients within $31-40$ years age group.

The high prevalence of tuberculosis infection in male patients in the current study is in consonant with [15] who reported that higher prevalence (12.67\%) of pulmonary tuberculosis among male HIV/ AIDS subjects than in the female (2.66\%).

Higher infection among patients with lower CD4 cell count in this study agrees with [16] who reported the prevalence of $90.91 \%$ in patients with CD4 $<200$, 21.21\% among those with CD4 between 200-349, $23.81 \%$ among those with CD4 of 350-499 while the least infection (11.43\%) was found among patients with CD4 < 500. Similarly, [17] reported that lower CD4 cell counts in HIV/AIDS patients were associated with increasing rates of malaria which was $44.12 \%$ at CD4 cell counts less than 200 cells/ $\mu \mathrm{L}$ while $40.38 \%$ were recorded at CD4 cell counts greater than 200 cells $/ \mu \mathrm{L}$. This scenario is contrary to [15] who reported higher (47 83\%) prevalence of tuberculosis infection in patients with CD4 $<350$ than $39.13 \%$ recorded in patients with CD4+ T cells count less than 200 cell/ $\mathrm{mm}^{3}$. Thus with opportunistic infection of TB CD4+ T cells count was drastically lowered. Cryptosporidiosis is a disease caused by protozoan parasites infecting large bowel and extraintestinal mucosa causing diarrheal illness among immunocompromised patients. There are three species causing cryptosporidiosis: Cryptosporidium hominis, C. parvum and C. meleagridis. Out of which, $C$. parvum has been commonly reported from HIV positive patients. HIV patients having $\mathrm{CD} 4+\mathrm{T}$ cell count $<100$ cells $/ \mu \mathrm{l}$ of blood are at greater risk. Usually disease resolves within 14 days in HIV patients having CD4+ T cells count $>200$ cells/ $\mu \mathrm{l}$ of blood [18]. Diarrheal cases have demonstrated a CD4 count between $200-499$ cell $/ \mathrm{mm}^{3}$, whereas a case of toxoplasmosis was demonstrated below 200 cell $/ \mathrm{mm}^{3}$ count [10]. $85.82 \%$ of patients with $\mathrm{CD} 4+\mathrm{T}$ cells count $<200$ cells $/ \mu$ l had the highest infection for enteric parasites compared with $63.07 \%$ and $26.94 \%$ in patients CD4+T cells count of $200-500$ and $>500$ respectively [11].

\section{Conclusion}

In conclusion, this study showed malaria as the most common infection followed by tuberculosis in patients with HIV/AIDS with CD4 count below 200 as the country and state is endemic to such disease and it was severe in patients with HIV/AIDS infection and from the results they do not know they have the infection in them. It is probably that highly active antiretroviral therapy (HAART) greatly contributed to the reduction in the frequency of opportunistic infections. Although effective treatment options are available, in most cases patients develop an opportunistic infection. The earlier a health care provider is contacted about any symptoms, the sooner one get diagnosed and treated, and the better the chances that the treatment work and make full recovery.

\section{Acknowledgements}

We would like to acknowledge the management and staff of Faith Alive Hospital for the permission to conduct this study in their clinic. We also thank the HIV/AIDS patients for their acceptance to participate in the study.

\section{References}

1. Christopher L, Nissapatorn V, Quek KF, Khairul AA (2003) AIDS related opportunistic infections in Hospital Kuala Lumpur. Jpn J Infect Dis 56: 187-192.

2. Dhungel BA, Dhungel KU, Easow JM, Singh YI (2008) Opportunistic infection among HIV seropositive cases in Manipal Teaching Hospital, Pokhara, Nepal. Kathmandu University Medical Journal 6: 335-339.

3. Kaplan JE, Masur H, Jaffe H, Holmes KK (1995) Reducing the impact of opportunistic infections in patients with HIV infection. JAMA 8: 347-348.

4. Babu ASSR, Chandra TJ, Ramachandramouli B, Kumari RL (2014) Opportunistic Infections Vs Immune Suppres- 
sion Among HIV Seropositive Individuals in East Godavari District, Andhra Pradesh. Global Journal of Medical research (C): Microbiology and Pathology 14: 14-20.

5. Malwal FM, Muriuki G, Maru SS, Mwangangi EM (2016) Prevalence of Opportunistic Infections in HIV infected adult patients at Kenyatta National Hospital, Kenya. African Journal of Pharmacology and Therapeutics 5: 163-168.

6. Stein DS, Korvic JA, Vermund SH (1992) CD4+ lymphocyte cell enumeration for prediction of clinical course of Human Immunodeficiency Virus Disease. Journal of Infectious Disease 165: 352-363.

7. Saidu AS, Bunza MDA, Abubakar U, Adamu T, Ladan MJ, et al. (2009) A survey of opportunistic infections in hiv seropositive patients attending major hospitals of Kebbi State, Nigeria. Bayero Journal of Pure and Applied Sciences 2: 70-74.

8. Mariam ZT, Abebe G, Mulu A (2008) Opportunistic and other intestinal parasitic infections in aids patients, HIV seropositive healthy carriers and HIV seronegative individuals in southwest Ethiopia. East Afr J Public Health 5: 169-173.

9. Cheesbrough M (2006) District laboratory practice in tropical countries. New York Cambridge Press part II, Pp. 173368.

10. Jain S, Singh AK, Singh RP, Bajaj L, Damle AS (2014) Spectrum of opportunistic and other parasites among HIV/ AIDS patients attending a tertiary care hospital. Asian Pacific Journal of Tropical Disease 4: 480-483.

11. Venkatesh NR, Ravichandraprakash H, Ukey PM, Vijayanath V, Shreeharsh AG, et al. (2012) Opportunistic intestinal parasitic infections in hiv/aids patients presenting with diarrhea and their correlation with $\mathrm{Cd} 4+$ T-lymphocyte counts. International Journal of Pharmacy and Biological Sciences 2: 293-299.

12. Kim YJ, Woo JH, Ja Kim M, Park DW, Song J, et al. (2016) Opportunistic diseases among HIV-infected patients: a multicenter-nationwide Korean HIVIAIDS cohort study, 2006 to 2013. Korean J Intern Med 31: 953-960.

13. Rubaihayo J, Tumwesigye NM, Konde-Lule J, Wamani $\mathrm{H}$, Nakku-Joloba E, et al. (2016) Frequency and distribution patterns of opportunistic infections associated with HIV/ AIDS in Uganda. BMC Res Notes 9: 501

14. Iliyasu MY, Wana MN, Garba ZT (2017) Prevalence of cryptosporidiosis and isosporiasis among HIV-positive patients attending some hospitals in Bauchi Metropolis. Nigerian Journal of Parasitology 38: 79-84.

15. Ali A, Ahmad F, Imran M, Atif M, Noor Y, et al. (2016) Prevalence of pulmonary tuberculosis in HIV/ AIDS subjects. Austin Virol and Retrovirology 3: 1023.

16. Borle M, Agarkhedkar Sr, Sunkoj Y (2016) Opportunistic Infection among HIV Infected Children and Their CD4 Cell Correlates. Journal of Dental and Medical Sciences 15: 1-07.

17. Pam CR, Abubakar BT, Inwang GO, Amuga GA (2018) Malaria in immune-uppressed individuals on antiretroviral therapy (ART) in north-central Nigeria. Nigerian Journal of Parasitology 39: 19-23.

18. Sandhu A, Samra AK (2013) Opportunistic infections and disease implications in HIVIAIDS. International Journal of Pharmaceutical Science Invention 2: 47-54. 